\title{
On Testing and Assessment of Oral English for English Majors: An Empirical Study
}

\author{
Huijuan Xue \\ Humanities and Management \\ Jiangxi Police Institute \\ Nanchang, China \\ xuehuijuan1@yahoo.com
}

\begin{abstract}
This paper explores how to break the single teaching result evaluation, to balance and integrate formative and summative assessments and to measure and test learners' oral English language proficiency against the background of MOOC, Micro-Class, Flipped Classroom and SPOC teaching modes. It takes "Oral English 3" as an illustration and finds that formative assessment improves teaching effects and learning outcomes. Characterized by monitoring students' learning and providing ongoing feedback, such an assessment can help learners identify their strengths and weaknesses and target areas that need work, foster learning autonomy and promote academic success. It concludes that integrating formative and summative assessments can enhance students' abilities to make PPT presentations and develop their competence in thinking, oral expression and communication in English, thus generating positive washback effects.
\end{abstract}

Keywords-Assessment and testing; Oral English online course; Formative and summative assessments; Washback effect

\section{INTRODUCTION}

Thanks to information technology in the "Big Data" age, MOOC (Massive Open Online Courses), Micro-Class, Flipped Classroom and SPOC (Small Private Online Courses) are changing people's lives in many ways, including teaching and learning modes. Learning mode has shifted from centering on traditional textbooks and pattern-drill exercise-books to that being characteristic of blended (online / offline) and independent learning. The new tendency reveals the integration of different forms of teaching and learning: classroom and out of class, online and offline, digital and paper teaching materials, artificial intelligence and teacher involvement. Against such a background of brand-new teaching and learning styles, how to break the single teaching result evaluation, to balance formative and summative assessments and to evaluate and test learners' oral English proficiency is one of the greatest challenges educators face in the new era.

\section{AN OVERVIEW OF ENGLISH LEARNING ASSESSMENT, EVALUATION AND TESTING}

Testing is an important way to assess teaching quality, evaluate teaching effects and measure whether students have acquired the knowledge transmitted. Tests exert a powerful influence on language learners who are preparing to take exams. Washback or backwash effect, a common term used in applied linguistics, refers to the impact that tests have on teaching and learning. As early as 1988, Pearson pointed out that "it is generally accepted that public examinations influence the attitudes, behavior, and motivation of teachers, learners and parents ..."[1] According to Wall \& Alderson, "It is common to claim the existence of washback and to declare that tests can be powerful determiners, both positively and negatively, of what happens in classrooms"[2]. Andrews and Fulllove stated "Not only have many tests failed to change, but they have continued to exert a powerful negative washback effect on teaching" [3]. While washback effect is widely perceived to exist, not many empirical studies have been made to confirm or deny such perceptions. Nevertheless there has always been a great interest in testing because people hope such studies can improve teaching quality and effects.

Research on English language testing conducted by educators cover "listening, speaking, reading, writing, translation, vocabulary and grammar" and so on. Comparatively speaking, studies on oral English tests seem to be more complex. In China, because of the fact that teachers stress intensive reading and listening more at the cost of neglecting the development of learners' oral English language proficiency in the whole process of College English teaching, encouraging students' to take oral tests is difficult which makes it impossible for CET-4/6 oral tests to have any scale. However, with more emphasis on English learners' oral competence in the English education sector, Zhang primarily investigated establishing College English Oral Test System via small-scale practices [4]. He designed College English tests by adding oral tests step by step in four semesters so as to supplement the limited coverage of CET. In carrying out the research and practicing "Spoken English Test for College English Application Ability", Yan and her colleagues pointed out that spoken English tests have problems including unreasonable curriculum structure, outdated teaching contents and the imperfect test and evaluation system [5]. They suggested that 
spoken English teaching shift from audio-visual-based to speaking-oriented teaching, thus establishing a more perfect, scientific and reasonable evaluation system. Xu probed into the content, methods and effects of integrating English public speaking skills in postgraduates' oral test and evaluation system. She concluded such an oral test system would not only make postgraduates attach importance to the development of public speaking skills but also enable students to internalize what they have learned and put into practice [6].

When Communicative Approach is widely advocated and practiced in the English world, how to use the language in real life situations to measure testees' English proficiency is challenging. Generally speaking, communicative tests are context-specific. To simulate real life communicative situations and to test learners' linguistic and communicative competence puts high demands on both students and teachers in the information technology age. At present, test and assessment innovation in oral English courses mostly remains at a conceptual and thinking stage, lacking in empirical studies. This paper will take "Oral English 3" online course for English majors as an example for an empirical study on the new testing and evaluation mode.

\section{AN EMPIRICAL STUDY ON TESTING AND ASSESSMENT OF ORAL ENGLISH FOR ENGLISH MAJORS}

\section{A. "Oral English" Teaching Practice}

A set of textbooks for "Oral English" published by Beijing Foreign Studies University is used to teach Level-1 and Level2 English majors in Jiangxi Police Institute. "Oral English" is a compulsory foundation course and its teaching objective is to gradually develop and enhance learners' oral English communicative competence through oral practice as well as enrich their cultural knowledge of English-speaking countries. Not only does the course highlight the development of learners' applied linguistic competence but also underlines the cultivation of cross-cultural communicative competence. "Oral English 1" emphasizes the English language input, reinforces practice to lay a solid foundation so that students can have proper conversations in common daily situations and talk about simple general social topics with acceptable pronunciation and intonation, good grammar and appropriate expressions.

"Oral English 2" requires students firstly to have good pronunciation and intonation, secondly to communicate on daily and social topics with fluent English and lastly to stress the development of critical thinking, all these requirements leading to a good foundation for oral communicative competence. The author also starts to preliminarily train students in making PPT oral presentations from Book 2 onwards. "Oral English 3" requires learners to make comparatively fluent and coherent talks and communicate on various daily and social topics, especially on hot social issues. Students are supposed to have quite long communications with native-speakers on their society and culture with appropriate expressions. Book 3 underscores the development of applied linguistic competence, critical thinking and analytical mentality, reinforces the cross-cultural communicative awareness and fosters oral communicative competence. At the same time, it focuses on improving students' abilities to make PPT presentations, aiming at raising their oral English language proficiency to an intermediate level. Apart from requiring learners to have natural talks and communications on diverse daily and social topics in English, "Oral English 4" sets requirements for students to search the Internet, to review literature and to have free conversations and debates on hot social issues with fluency and coherence, thus training and cultivating their analytical competence and English debating skills. Learners are supposed to complete such tasks with appropriate expressions, critical thinking and synthesizing capabilities, thus raising the oral language proficiency of most students to an intermediate level.

The "Oral English" course puts a premium on practice (teaching and practice both accounting for half the time), with practice aiming at developing students' English linguistic and oral communicative competence. "Oral English 2-4" requires students to search, select and synthesize web learning resources, practice making PPT slides and give oral presentations. The module enriches second classroom language practice via organizing activities like "English Corner", "English Salon", "English Speech Contest" and encouraging students to participate in National English competitions. Starting from September 2017, the author has been practicing the online teaching of "Oral English 3". Such an online course enables students to learn English with richer online / offline resources of PPT talks, audio-videos, movie clips and successful English speech contests [7].

Typically, oral English teaching starts from the teacher's PPT lecture [8]. If the theme is simple and easily understood, sometimes the unit starts from students' oral presentations in groups. Take "Unit 3: Growing Pains" from "Oral English 3" online module as an example. The author starts the unit by giving a PPT talk, making a point of the "generation gap", illustrated by the movie clip of "Generation Gap", from the famous British comedy by French and Saunders. The video clip of about 3 minutes is full of scenes of the gap issue caused by different tastes for music, living styles, habits and pursuits. With such typical generation gap problems to start Unit 3, students immediately have things to say. They throw themselves into warm discussions, comparing and contrasting similarities and differences with their parents in clothing, music, reading and hobbies and so on, and sharing their unpleasant experiences with parents in class. Likewise, the picturedescribing task "For Better or for Worse" that involves students telling stories based on a series of pictures supplements their knowledge about the topic. Furthermore, the PPT talk covers the roles of parents, teachers and peers in the process of socialization and compares the importance of each role.

Apart from imparting knowledge about the theme, the PPT talk also adds vocabulary on "growing pains" and "generation gap" so as to enable learners' to build up words and expressions to be actively involved in discussions, thus enhancing classroom interactions. After their deep understanding and good mastery of the contents, students are required to search relevant information on the Internet, or to refer to textbooks and the PPT talks and audio-videos and such like that the author uploads on the website for the online module, to prepare PPT slides and give oral presentations in 
groups in class. Finally, learners are asked to have discussions at a deeper level on pertinent questions like "How important is discipline to the growth of adolescents?" and "Who do you think play a more important role in shaping your character: parents, teachers or peers? Why?" A unit's teaching in the online course starts from the teacher's PPT talk, followed by warm-up discussions, vocabulary builder, students' PPT presentations, teacher's evaluation, learners' self-assessment, peer comments and deep-level discussions, with audio-video clips and supplementary teaching resources enriching learners' knowledge. By teacher's explaining profound meanings in simple language, students not only obtain rich knowledge about the theme but also acquire adequate vocabulary to join in discussions, leading to the improvement of their abilities to make PPT presentations and enhancement of competence in critical thinking, oral English expression and communication [7]. "Oral English" principally adopts Communicative Approach and Situational Teaching Method. To integrate the two methods, especially to practice the online course teaching is to improve students' applied linguistic skills and to enhance their oral English communicative competence in a real sense.

\section{B. An Empirical Study on Testing and Assessment of Oral English for English Majors}

Testing is an important component in English teaching, and it is used to test and assess how learners acquire knowledge and English linguistic skills. Formative assessment underlines students' learning process, varying in evaluative tasks. It is a test showing formative evaluations in the process and results of testing, revealing the reflections of both teachers and students on learners' academic progress during a certain learning period. Formative assessment may include several quizzes in the whole learning process of a certain module or it may comprise several tasks in diverse forms to be completed. Its aim is to evaluate students' learning performances, to diagnose their knowledge structure, to emphasize feedback after tests, to boost learning autonomy and to provide dynamics and drive for academic success. In contrast, traditional summative assessment principally serves as tests and evaluation. It assesses and verifies students' academic achievements with final scores when a certain module comes to an end, thus measuring and testing students' learning outcomes [9-10].

The test and evaluation in "Oral English" is normally divided into two parts: 1. formative assessment (30\%); 2. summative assessment (70\%). Formative assessment is mainly reflected in students' performances at ordinary times, depending on their practice at completion, group / individual presentations, engagement and interaction in class and so on, but in fact the evaluation of ordinary performances are somewhat arbitrary. The summative assessment at the end of the term is carried out based on the teaching requirements of the module, with the content being tested closely combining with the teaching materials learned. Although "Oral English 3" online course does not differ from the traditional teaching in grade percentages for ordinary performances (30\%) and the end-term oral test $(70 \%)$, it not only examines students' learning results but also attaches importance to their learning process. Grades for ordinary performances comprise two parts: online and offline, the former covers completing the tasks of watching videos and listening to audios online as well as the number of visits students pay to these multimedia tasks. The latter primarily refers to the completion of PPT talks (involving paper slides and group oral presentations and teamwork), individual classroom engagement and participation and attendance rates as well (see Table I). Such an evaluation and test for "Oral English" fully shows the advantages of formative assessment, measuring such factors as learners' real performance in the learning process and incorporating teachers' evaluation and assessment, students' self-appraisal and peer comments.

TABle I. Testing \& Assessment Elements in “Oral English 3" Online Course

\begin{tabular}{|c|c|c|c|c|c|c|c|}
\hline \multicolumn{6}{|c|}{ Ordinary Performances ( $30 \%$ ) } & \multirow{2}{*}{\multicolumn{2}{|c|}{$\begin{array}{c}\text { End-term } \\
\text { Oral Test }(\mathbf{7 0 \% )}) \\
\text { PPT Presentation } \\
(\mathbf{1 0 0 \% )}\end{array}$}} \\
\hline \multicolumn{2}{|c|}{$\begin{array}{c}\text { Online ( } 40 \% \text { ) } \\
\text { ( Watching Videos / } \\
\text { Listening to Audios ) }\end{array}$} & \multicolumn{4}{|c|}{ Offline ( $60 \%$ ) } & & \\
\hline \multirow{2}{*}{$\begin{array}{c}\text { Tasks } \\
20 \\
(25 \%)\end{array}$} & \multirow{2}{*}{$\begin{array}{c}\text { Numbers of } \\
\text { Visits } \\
140 \\
(15 \%)\end{array}$} & \multicolumn{2}{|c|}{ PPT ( $45 \%)$} & \multirow{2}{*}{$\begin{array}{c}\text { Individual } \\
\text { Classroom } \\
\text { Engagement and } \\
\text { Participation } \\
(10 \%)\end{array}$} & \multirow{2}{*}{$\begin{array}{l}\text { Attendance } \\
\text { Rates } \\
(5 \%)\end{array}$} & \multirow{2}{*}{$\begin{array}{c}\text { PPT Slides } \\
(40 \%)\end{array}$} & \multirow{2}{*}{$\begin{array}{c}\text { Oral } \\
\text { Presentation } \\
(60 \%)\end{array}$} \\
\hline & & Paper Slides & $\begin{array}{c}\text { Oral Presentation } \\
\text { (Teamwork) }\end{array}$ & & & & \\
\hline
\end{tabular}

The online course of "Oral English 3" requires students to search for relevant materials on the Internet and use various learning resources to complete PPT slides on the topic in groups through self-study before learning the new unit. Each unit is taught within 4 classes, each taking 45 minutes, over two days. In the first two classes, some groups take the stage to make PPT presentations in English. In order to ensure the quality of practice, the whole class and teacher make comments and give feedback after listening. Based on such remarks and reactions, students are asked to improve their PPT talks, correct spelling mistakes, improper collocation and typos and adjust formatting (including correcting pronunciation). Students hand in PPT slides in paper form (as mandatory task for practice reports) and electronic version (to be uploaded online in a special column for sharing) on returning for the follow-up class. In the course of completing the practical task, the author carefully observes, records students' real performances at practice, makes elaborative comments and evaluates strictly according to the measurement criteria.

The topics for the end-term oral test come from the units taught, and students are required to familiarize themselves with 
the themes and prepare PPT slides and oral presentations, of which PPT preparations accounts for $40 \%$ and presentation, $60 \%$ (see Table I). Students randomly select from the five topics given and take oral test on the spot, which takes about 4 minutes. The difficulty level of the test is consistent with curriculum requirements, and the content is both relevant to the textbook and flexible, giving learners the space to play freely. The specific assessment and evaluation criteria for the endterm test are principally based on PPT preparations (including wording, collocation, idiomatic expressions, grammar, formatting, aesthetics, etc.), applied English linguistic skills (pronunciation, intonation, speed, the feel for English, fluency, coherence, consistence, the mastery of knowledge and the correctness of answers and so on) and other aspects (eg. naturalness, decency and such like).

\section{CONCLUSION}

English teaching is undergoing profound reform in content and methods with MOOC, Micro-Class, Flipped Classroom and SPOC being more and more widely practiced in the education sector. The single traditional summative assessment has become inadequate for the high teaching requirements in the new era. How to balance and integrate formative and summative assessments and to evaluate and test learners' oral English proficiency and communicative competence are real problems posed to educators that demand prompt solutions. However, due to the complexity of oral tests, research on testing and assessment of oral English for majors presently remains at a conceptual stage in China, lacking in empirical studies. Taking "Oral English 3" online course as an example, this paper makes an empirical study on the new testing and assessment mode for English majors and finds that the formative assessment improves teaching effects and learning outcomes. Such a formative assessment, characterized by attaching importance to students' learning process, monitoring learning outcomes and providing ongoing feedback, enables learners to identify their strengths and weaknesses and target areas that need work, fosters learning autonomy and promotes academic success. It concludes that an oral English test that integrates formative and summative assessments can boost learners' abilities to make PPT presentations and develop their competence in analytical thinking and synthesizing, oral expression and communication in English, thus producing positive backwash effects.

\section{REFERENCES}

[1] Pearson, I. (1988) "Tests as Levers of Change (or "putting first things first')". In D. Chamberlain \& R. Baumgartner (eds.), ESP in the Classroom: Practice and Evaluation (98-107), ELT Documents \#128. London: Modern English Publications in Association with the British Council.

[2] Wall, D. \& Alderson, J. C. (1993) Examining Washback: The Sri Lankan Impact Study. Language Testing, 10 (1): 41-69.

[3] Andrews, S. \& Fullilove, J. (1994) “Assessing Spoken English in Public Examinations - Why or How?" In Boyle \& P. Falvey (eds.) English Language Testing in Hong Kong (57-86) Hong Kong: Chinese University Press.

[4] Zhang X. "A Primary Investigation into the Oral Test System in College English", Foreign Language and Teaching, 2014, 1: 42-51.

[5] Yan J., Zhang, W., Yu, Y. \& Chang, J. "Research and Practice of Spoken English Test for College English Application Ability — A Case Study of Beijing Institute of Petrochemical Technology", Theory and Practice of Education, 2015, 15: 57-58.

[6] Xu, X. "Integration of English Speaking Skills in Postgraduate Oral Test and Evaluation", Overseas English, 2013, 1: 119-120.

[7] Xue, H. On Blended Learning and Oral English Communicative Competence - Taking "Oral English 3" Online Course as an Example. 2018 2nd International Conference on Management, Education and Social Science (ICMESS2018), Conference Proceedings, forthcoming.

[8] Xue, H. "On Teacher-Student Interaction in Oral English Teaching", Education Research Monthly, China, 2014, 1: 107-111.

[9] https://en.wikipedia.org/wiki

[10] http://facdev.niu.edu. 